\title{
Yamaubamotívumok értelmezése a japán népmesékben és legendákban
}

\begin{abstract}
A japán mesevilág, ahogy más népek mesevilága, bővelkednek természetfeletti lényekben, szellemekben, boszorkányokban, segítő és ártó mesebeli alakokban. Ezen alakok gyüjtőneve a japán nyelvben a yōkai 妖怪, amely többfajta szellemlényt foglal magába. ${ }^{1}$ Régen a japán ember képzeletében természetfeletti lények, istenek és szellemek népesítették be az ország nagy részét borító erdőket és hegyeket; történeteiket, és találkozásaikat az emberi világgal a népmesékben, legendákban és mítoszokban mesélték el. A japán néprajzkutatók között általánosan elfogadott elmélet szerint a yōkai eredetileg istenként tisztelt szellemlények voltak, amelyek később közelebb kerülvén az emberek világához mesebeli alakokként jelentek meg a népmesékben és a legendákban. A női alakok közül talán a legismertebb figura a yamauba ${ }^{2}$ 山姥, amely a nyugati mesekörben a boszorkány alakjához áll a legközelebb, habár számos tulajdonságában különbözik tőle. A yamaubatörténeteknek sok változata van, és ahogy a japán természetfeletti lények többségéről elmondható, úgy a yamaubát sem lehet egyértelműen besorolni a negatív vagy a pozitív figurák közé. Japánban először Yanagida Kunio 柳田国男 írt a yamauba alakjáról, majd később Yoshida Atsuhiko 吉田敦彦 foglalkozott mélyebben a yamauba eredetével és értelmezésével. ${ }^{3}$ Yoshida nevéhez füződik az az elméletet, amely a yama-
\end{abstract}

Sok más kifejezés használatos a természetfeletti lények megnevezésére, például a bakemono 化け物, obake お化け, yūrei 幽霊. Habár a populáris használatban nem különül el élesen az egyes kifejezések használata, a néprajztudományban a yūrei és yōkai különböző fajta szellemlényt jelöl. Továbbá a szellemlény isteni eredetére utaló kifejezés a shinrei 神霊, amely kamit (istenség), annak lelkét (kami no mitama 神の) みたま) vagy a kamivá vált elhunyt lelkét is jelenti. A japán néprajzban többfajta megkülönböztetése létezik a yōkaioknak, ezek közül az egyik a yōkai előfordulásának a helye szerinti megkülönböztetés: hegyek/erdők, utak, házak, vizek. Ld. Ōshima 2008, 994.

2 Másik olvasatában: yamanba. Yamanba olvasatát használják például a nō drámákban. Ld. Rumánek 2010: 371.

3 Ld. például Yanagida 1988 és 2013, továbbá Yoshida 1992. 
ubához kapcsolódó hitvilágot a Jōmon-kultúrából eredezteti. ${ }^{4}$ Jelen cikk ezt az elméletet, továbbá a legismertebb yamaubatörténetek motívumait mutatja be és elemzi.

A yamaubatörténetek Japán számos helyén hagyományozódnak mesék, legendák formájában. De nem csupán történetekben szerepel, hanem a népi hitvilágban is fontos szerepet játszik, hiszen több szokás és rituálé központi alakjaként is megjelenik. ${ }^{5}$ A népi hitvilágban elsősorban a termékenység és jó termés védőszellemeként tekintettek rá, és több régióban is a hegy istennőjeként tisztelték. Yoshida szerint a yamaubahit a Jōmon-kor anyaistenségével (oyagami 母神) és a vadászatistenségével (shuryōshin 狩猟神) függ össze, és ilyen értelmezésben a yamauba-hiedelemvilág szorosan kapcsolódik a világ egyéb részein is ismert teremtéslegendákhoz, amelyek az alapvető táplálékok és haszonnövények eredetének a történetét mesélik el. ${ }^{6}$ A legismertebb ezek közül a polinéziai Hainuwele-mítoszkör, amelynek jelentőségére Adolf Ellegard Jensen, német antropológus mutatott rá 1951-ben megjelent munkájában. ${ }^{7}$ Ezekben a történetekben a megölt istennő eltemetett testrészeiből különféle növények nőnek, amelyek az érintett nép fontos táplálékaivá válnak. Rokonságot mutatnak a Hainuwele-mítoszokkal azok a yamaubatörténetek, amelyekben az elpusztult yamauba véréből vagy testéböl haszonnövények vagy gyógynövények keletkeznek. Kapcsolódó motívum szintén, amikor a történetekben a yamauba bőséget és táplálékot adományoz a rajta segítő embereknek. ${ }^{8}$

Ide tartoznak továbbá az ún. ushikata- és umakatayamaubatörténetek, amelyek az egész ország területén hagyományozódnak. A mesének számos változata van, de a lényegi részében nem változik. Az ushikata 牛方 vagy umakata 馬方 szóval régen azokat a fuvarosokat jelölték, akik ökör (ushi) vagy ló (uma) segítségével szállították az árut vagy egyéb terhet egyik faluból a másikba. Yamauba a mindenki számára jól ismert alakjában jelenik meg ezekben a történetekben: csúf vénasszony óriási szájnyílással, amelyen keresztül felfalja áldozatait. A történetben yamauba megállítja a fuvarost az erdőben, majd felfalja a teherhordó állatot a szállítmányával együtt. Ekkor kerülne a sor a férfira is, de annak időközben sikerül elmenekülnie. Elrejtőzik egy erdei há-

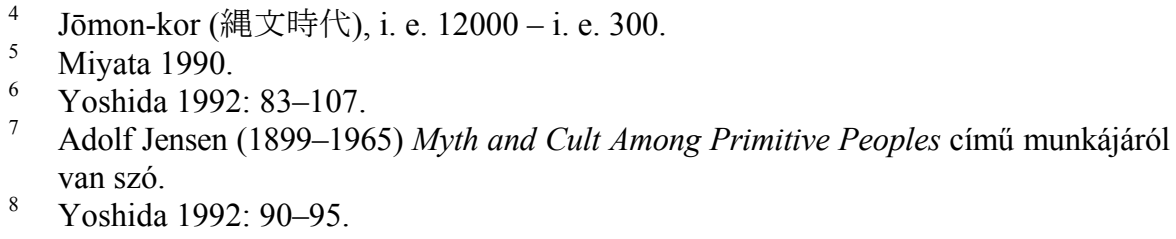


zikóban, amelyröl azonban kiderül, hogy a yamauba lakhelye. Yamauba a keresésben végül elfáradva visszatér otthonába, ott az ágyába fekszik, és elalszik. Ekkor előjön a rejtekhelyéről a férfi, és elégeti az alvó yamaubát. Testének maradványaiból a történet hőse varázsgyógyszert készít, és a környék falvaiban ezt árusítva meggazdagodik belőle. A történetnek több változata is ismert, de mindegyikben szerencsét vagy jólétet hoz a hősnek a yamauba halála. ${ }^{9}$

Miyagi és Aichi prefektúrákban ezzel a történettel magyarázták régen a $s o b a$ 蕎麦 (pohánka, avagy hajdina) és a fúszerpaprika (tōgarashi 唐辛子) piros színének az eredetét. A történet végén elpusztuló yamauba vére beszínezi ugyanis a növények szárát vagy gyökerét. További hasonló motívumok ismertek a japán mítoszokból is, ahol például Izanami 伊邪那美 istennő testéből születnek a különböző istenségek. Halálának módja is megegyezik a yamaubatörténetben leírtakkal: tüzben pusztul el. ${ }^{10}$ Yoshida több mítoszt is elemez, például a Kojikiben szereplő Ōgetsuhime ${ }^{11}$ mítoszát, akit a táplálék vagy gabona istennőjeként tiszteltek. A mítosz szerint az istennő a táplálékot saját testéből nyerte, és amikor a vihar és tengerek istene, Susano-o (須佐 之男) élelmet kér tőle, az istennő teste nyílásaiból kiszedett táplálékkal kínálta a hatalmas istenséget. ${ }^{12}$ Susano-o a tiszteletlenséget látva feldühödik, és megöli az istennőt. A halott istennő testéből haszonnövények keletkeznek, amelyek évszázadokon keresztül élelmet biztosítanak a japánoknak: rizs, bab, gabona, szója. Ezek a mítoszok valóban sok hasonlóságot mutatnak a yamaubalegendákkal, így valószínüsíthető a kapcsolat a mítoszokban szereplő istennők és a yamauba között.

A fent említett mesebeli természetfeletti lények isteni eredetének az elméletével japán kontextusban elöször Yanagida Kunio foglalkozott, többek között ezzel az eredettel hozta összefüggésbe azt a tényt, miszerint a yamaubának kettős természete van, tehát nem egyértelmű a besorolása a pozitív vagy a negatív lények közé. ${ }^{13}$ A yamauba isteni természetével magyarázható az a ket-

9 Yoshida 1992: 84-89. Egyes változatokban arannyá, illetve pénzzé változik a yamauba megégett teste.

10 Izanami, miközben a tüz istenének ad életet, maga elpusztul a szülésben.

11 Teljes nevén Ōgetsuhime-no-kami (大宜都比売神), avagy Ukemochi-no-kami (保食神) (táplálékot védelmező istenség). Az inari rókaszellemmel is összefüggésbe hozzák, amely a népi hitvilágban az istennő átváltozott alakjaként vagy annak házastársaként szerepel.

12 Yoshida 1992: 140-170.

13 Yanagida 1988. Yanagida értelmezését dolgozta tovább Yoshida 1992. 
tőség, miszerint a mesékben hol bőséget és szerencsét hoz az embereknek, hol megbünteti őket, attól függően, hogyan viselkednek vele. ${ }^{14}$

Itt szükséges megemlíteni a miko 巫女, avagy fujo (巫女) hagyományához való kapcsolódást is. Napjainkban a miko alatt a sintó szentélyek női kisegítöszemélyzetét értjük, régebben azonban ezek a sámánizmus technikáit is alkalmazó, sokszor vándorló életmódot folytató japán vidék alakjaihoz tartoztak. A mikókról azt vélték, hogy hasonlóan a többi, sámán hagyományhoz tartozó szereplőhöz, ők is az istenek világával tudnak kapcsolatot kialakítani, így közvetítve az istenek akaratát. Fontos szolgáltatásaik közé tartozott a halottak szellemeivel való kommunikálás, amely máig elmaradhatatlan része az ÉszakHonshū területein tevékenydő itako イタコ sámánnők gyakorlatának. ${ }^{15}$ Voltak szentélyeknél letelepedő mikók is, akik a sintószertartásokban segédkeztek, avagy azokat egyedül is végezték, ezeket jinja mikóknak (神社神子) nevezték. ${ }^{16}$ A mikók a népi hiedelem szerint az istenek szellemét hordozták magukban, ismertek olyan helyek is, ahol a sintó szentély „anyjának”, avagy az istenség hitvesének tekintették őket. ${ }^{17}$ Több szempontból is hasonlóságot mutatnak a mikókhoz füződő hiedelmek a yamaubát körülvevő legendákkal és hiedelmekkel. Hasonlóan a mikókhoz, a yamaubát is számos helyen a hegy szellemének vagy a feleségének tekintették. Ismertek azonban olyan legendák is, amelyekbena yamauba a hegy istenének a szülöanyjaként szerepel, ilyen például az Aichiból származó legenda, amelyben a yamauba három fia lesz a környék három hegyének az istene. ${ }^{18}$

A középkorban voltak olyan mikók is, akik vándorló életmódot folytattak, és szolgáltatásaikat faluról falura kínálták. Az ilyen vándorló, nem helyhez kötött életmódot folytató emberekre a falvakban élők bizalmatlansággal és félelemmel néztek, és gyakran természetfeletti erőket tulajdonítottak nekik. ${ }^{19}$ A találkozások a falutól távol eső helyen egy elhanyagolt külsejű asszonnyal, aki sem külső kinézetében, sem viselkedésében nem felelt meg a társadalom elvárásainak, számos legenda megszületésének adtak táptalajt. A valóság és

14 A mesék ilyen jellegü elemzéséhez ld. Kawai Hayao 河合隼雄 pszichológus tanulmányát (Kawai 1983).

15 Ld. Németh 2018 és Papp 2018.

16 Sakurai 2008: 617.

17 A mikók általában nem mentek férjhez, habár később, az Edo-kor környékén, voltak mikók, akik yamabushi 山伏, tehát hegyi remeték feleségei lettek.

A történetet Yanagida is említi (1988: 129).

19 A közösségen kívül élők társadalmi megítéléséről Japánban ld. Strausz Janka tanulmányát (2016). 
a képzelet gyakran összefolyt az emberek elméjében, ahogy a miko és a yama$u b a$ alakja és a nekik tulajdonított képességek is gyakran összefonódtak. ${ }^{20}$

A hegy, az erdő, az emberek által kevésbé lakott területek különös világot foglaltak el a falu emberének a képzeletében. ${ }^{21}$ A hegy hagyományosan a túlvilág, a halottak szellemének az otthona volt, és az emberek félelemmel vegyes tisztelettel tekintettek minden, ebből a világból érkezettre. A szent hegyek kultusza elterjedt volt Japánban, ahogy Ázsia más részein is, és máig fontos része a vallásos gyakorlatnak. ${ }^{22}$ Különösen a szép formájú hegycsúcsok vagy a hármas hegycsúcsok voltak tárgyai a vallásos tiszteletnek. A hegy istene, yama no kami 山の神 kultusza Japán egész területén megtalálható, és nagyon gazdag és változatos hagyomány kapcsolódik hozzá. A hegy istenének kultusza szorosan kapcsolódik a mezőgazdasághoz is, megtalálható nem csupán a rizstermeléssel foglalkozó közösségekben, hanem a vadászatból élő közösségekben is. A hegy istene nemét tekintve lehetett férfi és nő is, ám voltak helyek, ahol egy istenpár (meotogami 夫婦神) állt a kultusz középpontjában. ${ }^{23}$ A közelmúltig Japánban több szent hegy szakrális területére tilos volt a nők számára lépni - vannak helyek, ahol máig érvényes a tilalom. ${ }^{24} \mathrm{Az}$ általánosan elfogadott magyarázat a tilalomra általában a nők rituális tisztátalanságát hangsúlyozza ki. Ezzel kapcsolatban elmondható, hogy a középkorban a férfiközpontú hierarchikus társadalmi berendezkedés megerősödésével a nők rituális tisztátalanságának úgy buddhista, mint sintó szemlélete megerősödött. A sintó kozmológiában a vér hagyományosan rituális tisztátalanságot okoz, alapot adva ezzel a női léthez kapcsolódó tisztátalanság nézetére, hiszen a nők gyakrabban jönnek érintkezésbe életük során vérrel a menstruáció és a gyerekszülés miatt. A férfiakkal összevetve ezért nagyobb mértékü tisztátalanságnak voltak kitéve a hagyományos hiedelem szerint. ${ }^{25}$ Vannak azonban olyan magyarázatok is, amelyek a nők belépésének tilalmát a szent hegy szakrális területére a hegy istennőjének a féltékenységével magyarázták. Ezeket a tilalmakat álta-

20 Hasonló folyamatnak lehetünk tanúi a tengu és a yamabushi esetében.

21 Yanagida 2013

22 A szent hegyek kultuszának Ázsia különböző kultúráiban betöltött szerepét vizsgálja a 2018-ban megjelent Szent hegyek a buddhizmusban címü kötet (Hamar-GelleKósa 2018).

23 Ōshima et al. 1990, 181.

24 Ilyen például az Ōmine hegység Naraprefektúrában, a shugendō 修験道 (japán hegyi aszketikus rend) kultikus helyszíne, ahol ma is érvényes a tilalom (ld. Kobayashi 2017).

25 Kawade 1986: 142. Ld. továbbá a témában magyar nyelven Papp 2018. 
lában tiszteletben tartották, ugyanis annak be nem tartása az istenség haragját és bosszúját vonta volna mind az egyénre, mind a közösségre.

A hegy területe és az ott élő emberekkel kapcsolatos további érdekes jelenség a japán folklórban a kamikakushi 神隠 $L$, szó szerinti fordításban: „istenek által eltüntetve”. Kamikakushi szóval illették régen a falusiak azokat a történéseket, amikor valaki a faluból, általában gyerek vagy fiatal felnőtt, megmagyarázhatatlan módon eltűnt. ${ }^{26} \mathrm{Az}$ esemény köré gyakran legendákat szőtt a falu népe, amely segített, hogy a megmagyarázhatatlant megmagyarázzák. A hiedelem szerint ilyenkor az elkóborolt gyerekeket vagy fiatalokat természetfeletti lények tüntették el hosszabb vagy rövidebb időre. Sok helyi legenda mesél a kamikakushiról. Ilyenkor az előkerült gyerekek különös helyeken bukkannak fel, például emberek számára nehezen elérhető helyen: egy magas fa tetején, szakadékban vagy meredek sziklán. A természetfeletti lények között, akiknek a népi képzelet a kamikakushit tulajdonította, találjuk a yamaubát is. ${ }^{27}$

\section{Yamauba és a yakibatake}

A yamaubatörténetek jelentős része az égetéses-irtásos földmüvelést folytató közösségek szájhagyományához kapcsolódik. Japánban az új termőföldek nyerésének egyik hagyományos módja volt az erdők és a bozótos részek felégetése. ${ }^{28} \mathrm{Az}$ égetéses-irtásos földművelés során az új erdőterületek irtására és felégetésére került sor, amellyel a felszíni réteget is termővé tették, egyben az égetés megtisztította a területet a különféle kártevőktől is. Ezt az eljárást nevezték japánul yakibatake 焼き畑 (yakihata) földművelésnek, ${ }^{29}$ és egészen az 1960-as évekig alkalmazták, amikor is a modern technológiák felváltották a hagyományos gazdálkodásmódot. Az égetés számos nehézséggel és veszéllyel is járt, a kiszemelt terület megtisztításához több férfi munkájára volt szükség. Óvatosan kellett eljárni, hogy ne sérüljön senki, és hogy megakadá-

\footnotetext{
26 Komatsu 1991.

27 További gyakori szereplői a kamikakushi történeteknek a róka (kitsune 狐), tengu 天狗 vagy a kakurebaba 隠れ婆 (elrejtő vénasszony) (Konno 2008: 167).

28 Trópusi gazdálkodási és termesztési forma, amely általában intenzív kihasználással párosul, és ezért csak rövid ideig tartó megoldást nyújt az öntözéses kultúrákkal szemben. Ld. A. Gergely 2010: 107.

29 Szószerinti fordításban felégetett földet jelent. A yakibatakegazdálkodásról részletesebben ld. Chiba 1993.
} 
lyozzák a tüz elterjedését a környéken. Ahogy a rizsgazdálkodás rányomta bélyegét a közösség életmódjára, meghatározva évszázadokon keresztül a társadalmi berendezkedését, úgy az irtásos gazdálkodás is egy sajátos életmódot, szokáskultúrát és hiedelemvilágot alakított ki, amely tükröződik az itt hagyományozódó legendákban, népmesékben és rítusokban is. ${ }^{30}$ Míg a rizsgazdálkodásból élő falvakban jellemzően a tavasszal a hegyekből érkező yama no kami védelmezte a vetést és a termést ta no kamiként 田の神 (rizsföldek istene), ${ }^{31}$ addig a yakibatakeközösségek hitvilágának központi motívuma gyakran a yamauba volt. Itt a yamauba töltötte be falusi közösségek védelmező istenségének a szerepét. ${ }^{32}$ Ahogy a rizstermesztéssel foglalkozó falvakban a ta no kamihoz fohászkodtak a gazdag termésért, úgy a yakibatakefalvakban a yamauba állt ezen fohászok és rítusok fókuszában. Egy új földterület égetéses megtisztítása elött szokás volt egy rítus keretében a környék legmagasabb fája alatt összegyülni és ott felajánlásokat tenni a yamaubának. Kyūshūn például, ahol az irtásos technológia elterjedt volt, különösen nagy számban élnek yamauba legendák. Az egyik legismertebb, az ország egyéb területein is megtalálható történet a három fivérről szóló Tentōsan kane no tsuna (天道 さん金の綱 Az istenség arany kötele). A történetben az erdőben a yamauba azzal fenyegeti a három fiút, hogy felfalja őket, ezért ők félelmükben felmásznak egy magas fára, és ott az isteneket kérik, hogy eresszenek le nekik egy kötelet, amelyen felmászva megmenekülhetnének. A kívánságuk teljesül, és egy aranykötél ereszkedik le. Ezt látva a yamauba is felmászik a fára, és az ő kérése is teljesül. Ám neki egy elhasználódott, sáros kötél ereszkedik le, amely elszakad, a yamauba pedig lezuhan a mélybe, és elpusztul. A lehulló véréböl soba keletkezik, más verziókban a sobát festi be pirosra. A soba fontos termesztett növény volt a yakibataketechnológiával megmüvelt területeken. Kōchi prefektúrából származó történetekben a yamauba gyakran hoz szerencsét vagy balszerencsét az embereknek attól függően, hogy miként viselkednek vele. Gyakori motívum a yamauba átka is, amikor is az erdő felégetésével az emberek a halálát okozzák, amiért ő szerencsétlenséget hoz az egész falura.

További gyakori típusa a yamaubalegendáknak a kuwazu nyōbō 食わ ず女房 (a nő, aki nem eszik) történet, amelynek változatai az ország egész területén ismertek. A történetek egy fiatal férfiról szólnak, aki barátai kér-

\footnotetext{
30 Ld. Mizoguchi 1989.

31 Ősszel a betakarítás után a ta no kami újra visszatér a hegyekbe, hogy ott a hegy isteneként töltse el a telet a következö tavaszig.

32 Yoshida 1992.
} 
désére, hogy miért nem házasodik meg, azt válaszolja, hogy neki csak olyan menyasszony kell, aki nem eszik, és így nem kerül pénzbe. Röviddel ezután megjelenik egy szép fiatal leány a férfi házánál, aki azt állítja magáról, hogy nincs szüksége ennivalóra. Összeházasodnak, és minden rendben tünik addig, míg a férfi meg nem pillantja felesége valódi alakját. A fiatal nő valójában yamauba. Bosszúból, hogy férje felfedezte titkát, elhurcolja őt az erdőbe. A férfi végül úgy menekül meg, hogy elrejtőzik shōbu (菖蒲 írisz) és yomogi (蓬 zsálya) közé, amelyektől a yamauba retteg. Vannak olyan változatok is, amelyekben a férfi nem menekül meg, hanem felfalja őt egy félelmetes, óriási pókká átváltozott yamauba. ${ }^{33}$ A két említett növényt, íriszt és zsályát, hagyományosan a gonosz szellemek és ártó erők elüzésére használták a népi mágiában. ${ }^{34}$ A tango no sekku 端午の節句 évszakünnep ${ }^{35}$ alkalmából a házak ajtói fölé akasztottak a két növényböl füzött csokrot, hogy távol tartsák a tüzet, a betegséget és az egyéb ártó erőket. A növényekből fürdővizet (shōbuyu 菖蒲湯) is szoktak készíteni azzal a céllal, hogy a betegségeket okozó rossz szellemeket távol tartsák. ${ }^{36}$

\section{Kintarō és yamauba}

A gonosz yamaubatörténetek mellett egyértelmüen pozitív figuraként jelenik meg a yamauba a Kintarō-féle legendákban. Több ismert változata is van a történetnek, amelynek hőse az aranyhajú kisfiú, Kintarō 金太郎. ${ }^{37}$ A legenda szerint a természetfeletti erővel rendelkező kisfiút egy yamauba szülte, apja pedig a vihar istene, raijin (雷神) volt. A különböző történetek közös alapja

33 A történetnek számos változata ismert. A yamauba helyett oni 鬼 (ördög) vagy kumo クモ (pók) is szerepel ezekben a változatokban. A történet a tango no sekku 端午の節, ma kisfiúk ünnepeként ismert évszakünnep eredetének a magyarázatául is szolgál.

34 Az shōbut gyógynövényként is használták Kínában és Japánban is. A Kínából származó gyógynövények használati módjáról Japánban ld. továbbá Zentai 2015.

35 Tango no sekku ma az ötödik hó ötödik napján tartott kisfiúk hagyományos ünnepét jelenti (más néven koinobori 鯉のぼり). Május ötödike ma hivatalosan gyereknap is Japánban.

36 Az egészséggel és gyógyítással kapcsolatos korabeli szemléletet a következő magyar nyelvü tanulmányok tárgyalják: Zentai 2015; Papp-Zentai 2018.

37 Kintarō alakja egy történelmi személy alakjához füződik, amely vélhetően a 10. században élt, valós nevén Sakata no Kintoki 坂田金時, akinek számos höstettet tulajdonít az utókor. A hös legendája az évszázadok során kibővült különböző mesebeli motívumokkal. 
a gyermekáldás után áhítozó yamauba, aki miután álmában egy sárkányistenséghez megy feleségül, rövidesen egy aranyhajú kisfiúnak ad életet. A kisfiú csodálatos képességekkel rendelkezik, és mivel az erdőben nő fel, az állatok is a barátai. Amikor felnőtté cseperedik, természetfeletti erejének a híre eljut egy gazdag úrhoz, aki megkéri, hogy győzze le a környéken garázdálkodó ördögöket (oni 鬼). Kintarō sikeresen teljesíti a feladatot. A motívum az Edo-kori mủvészeket is megihlette, jól ismertek például a XVIII. századi Kitagawa Utamaro 喜多川歌麿 ukiyoe 浮世絵 képei a fiatal nőként megjelenített yamaubáról, aki karjában a kisgyermek Kintarōt tartja. Az egyik népszerü képen yamauba kisfiát tejével táplálja. ${ }^{38}$

\section{A szülés védelmezője és az adakozó yamauba}

Shikoku vidékén is több yamaubalegenda hagyományozódik. Kōchi prefektúra egyes helyein például a yamaubát a szülés istennőjeként tisztelik. Alakja valószínúleg szerepet játszott a mabiki 間引き, illetve a mizuko 水子 gyakorlatában is, amelynek során a nem kívánt vagy egyéb okból nem életképesnek ítélt gyermekeket közvetlenül születésük után megölték. ${ }^{39}$ Ilyenkor szokás volt a yamaubának „felajánlani” a mizukót, tehát az elhunyt csecsemő lelkét. Yamauba vajúdását megsegítő történetek is népszerúek. Itt általában az erdő mélyén magányosan vajúdó yamauba segítséget kér egy arra tévedt vándortól, vadásztól vagy favágótól, akit aztán a segítségnyújtásáért cserébe megjutalmaz valamivel.

Yamanashiból származik az a történet, amelyben egy fiatal lány megmenekül a yamaubától ajándékba kapott varázslatos köpönyegnek köszönhetően. Számos más történetben is a yamauba jótevőként szerepel, az általa adott szerencse, csodálatos tárgy végül azonban mégsem hoz jót az emberekre, mivel az ajándék feltételhez kötött. Az ígéretet az ajándékozott általában nem tartja be, és ezzel a yamauba haragját vonja magára. Az újévi szokásokhoz is kapcsolódnak történetek, amelyeknek számos változata ismert az országban. Ezekben a történetekben a yamauba december 28-án megjelenik a szegények otthonában, hogy ott csatlakozhasson az újévi rizskalács (shōgatsu mochi 正月餅)

\footnotetext{
38 A jelenkorban is népszerü figura az aranyhajú kisfiú, számos populáris kulturális megjelenítése (anime, manga, stb.) ismert.

39 Az Edo-korra jellemző magzatkép, születésszabályozás, illetve a mabiki gyakorlatáról ld. magyar nyelven Csendom 2018.
} 
készítéséhez. December 28-a az újévi rizskalácsok készítésének hagyományos napja Japánban. A yamauba látogatásával a jólétet és a szerencsét hozza el a szegényebb családokhoz. Az egyik történetben rendszeres látogatása eredményeként a család meggazdagodik, míg egyik évben a már meggazdagodott család nem engedi be többet a szakadt, rongyos ruhában érkező yamaubát. Cserébe az visszaveszi a családtól a gazdagságot és a szerencsét. Ezekben a történetekben a yamauba mint istenség jelenik meg, amely ahogy ad, úgy el is tud venni, ha feldühítik. Jellemző az is, hogy az általa ajándékozott dolgok gyakran mezőgazdasági termények, gyümölcsök, zöldségek, gazdag termés, de lehet ez akár szövet is. ${ }^{40}$ A Nunobikiyama 布引山 történetben a szövetet (nuno) sokszorosítja például. Tōhoku vidékein, ahol a vadászatot életmódként végző csoportok jelenléte jelentős volt, a yamauba gyakran a vadászokat védő istenségként jelenik meg. A vajúdó yamauba vagy az erdő mélyén kér segítséget a vadásztól, vagy a faluba megy le, hogy a falusiak segítségét kérje, és a szülésre alkalmas helyet kapjon. ${ }^{41}$ Hálából bőséget adományoz. Vannak olyan legendák is, amelyek a yamaubának többszörös gyermekszülést tulajdonítanak. ${ }^{42}$

Japán északi tartományaiban a yamauba gyakran a segítségért cserébe vadászszerencsét, élelmet vagy szövetet ajándékoz a vadásznak, a segítségnyújtás megtagadásáért viszont büntetést mér rá. Takashima felhívja a figyelmet arra, hogy a yamauba ezen jellegzetessége visszavezethető a Jōmon-kori hitvilághoz, amikor is a vadászó és gyüjtögető életmód volt jellemző a szigeteket benépesítő közösségekben. ${ }^{43}$ Habár Yoshida yamaubaelmélete inkább a mezögazdasági termények eredetmítoszaihoz vezeti vissza a yamauba istennő eredetét, egyúttal a yakibatake védőistenségeként betöltött szerepét hangsúlyozza ki, Takashima rámutat arra, hogy a Jōmon-korra inkább a vadászó-gyüjtögető életmód volt jellemző, mintsem a termőföld megmüvelése, habár kezdetleges mezőgazdaság már bizonyára létezett ekkor is. ${ }^{44}$ Ebben a vonatkozásban elmondható, hogy a yamauba értelmezésében jelentős szerepet játszhat a yama no kami (hegy istene) kultusza, hiszen a vadászó-gyüjtögető életmódot folytató közösségek hitvilágában különösen fontos helyet foglalt el a hegyek istene.

40 Ld. a cikk elején említett terméslegendákat ezzel kapcsolatban.

41

Takashima 2001: 125.

42 Matsuyama Yoshio által említett Nagano prefektúrában hagyományozódó legendában a vajúdó yamauba a hegység istennőjeként több tízezer gyermeknek ad egyszerre életet, bizonyítva ezzel isteni természetét és erejét (Matsuyama 1961, in: Takashima 2001: 126).

43 Takashima 2001.

44 Yoshida 1992; Takashima 2001: 123-125. 


\section{Összegzés}

A tanulmányban említett motívumok mind azt mutatják, hogy a yamauba fontos alakja lehetett a nagyon korai, kínai hatást megelőző japán hitvilágnak. Ebben a hitvilágban jelentős helyet elfoglaló női istenségek valószínüleg a későbbi yamaubalegendákban és -mesékben öltöttek részben alakot. A yamauba istennői természete nem csupán bőséget, élelmet, terményeket és jó szerencsét hozó képességeiben nyilvánul meg ezekben a történetekben, hanem a többszörös gyermekszülés képességében is. A yamaubához kapcsolódó mesék és legendák gazdag hagyományra vezetnek vissza, amelyben a teremtéslegendáktól kezdve egészen a termékenység, termés, vadászat és a szent hegyek kultuszáig a régi japán népi hitvilág számos motívuma képviselteti magát. A japán népmesék elemzése így a japán hagyományos hitvilág mélyebb megismerését teszi lehetôvé a figyelmes olvasó számára. Jelen tanulmány nem foglalkozott a yamaubamotívum szépirodalmi megjelenítésével, habár ennek is gazdag hagyománya van a japán irodalomban. ${ }^{45}$ A nō drámák egyik népszerü darabja Zeami alkotása, a Yamanba, amelyben a yamauba nem a mesékben fellépö félelmetes alakjában mutatkozik meg, hanem az embereket segítő szerepében. ${ }^{46}$ A yamauba szépirodalmi megjelenítésének mélyebb elemzése azonban egy külön tanulmányt érdemel.

\section{Felhasznált szakirodalom}

Csendom Andrea 2019. „A terhesség és magzat-kép az Edo-kor második felében: törvényeken, ōraimonókon és Kyōden gesakuján keresztül." Távol-keleti Tanulmányok 10 (1): 119-147.

Chiba Tokuji 千葉徳爾. 1993. „Tenryūgawa keikoku no yakibatake 天竜川渓谷の焼畑.” In: Yoshihiko Amino et al (eds.) Umi, kawa, yama no seisan to shinkō 海, 川, 山の 生産と信仰 (Nihon rekishiminzokuronshū 7. 日本歴民俗論集7). Tōkyō: Yoshikawa Kōbunkan, 2-26.

A. Gergely András 2010. „Égetéses-irtásos földmüvelés.” In: A. Gergely András, Papp Richárd, Szász Antónia, Hajdú Gabriella, Varga Andrea (szerk.): Antropológiai - etnológiai - kultúratudományi kislexikon. MTA PTI Etnoregionális és Antropológiai Kutatóközpont, Etnoregionális Munkafüzetek 108. Budapest: Magyar Kulturális Antropológiai Társaság, 107.

45 Köszönet a tanulmány bírálójának a szépirodalmi vonatkozás említéséért.

46 Nem minden szereplönek, de a yamaubának külön maszkja is van a nō hagyományban (Rumánek 2010: 277). Nō drámák olvashatók magyar nyelven is Kemenczky Judit fordításában (Kemenczky 1994). 
Hamar Imre - Gelle Zsóka - Kósa Gábor (szerk.). 2017. Szent hegyek a buddhizmusban. Budapest: ELTE BTK, A Buddhizmus-kutatás Központja.

Kawade Mieko 河出三枝子 1986. „Furikusa ni miru ubugoya no kosumorojii. Minzokugaku to rekishigaku no setten de 振草にみる産小屋のコスモロジー. 民俗学と歴史学の 接点で.” Kaison, nōsanson minzokuchōsa no kiseki to henyō. Segawa Kiyoko no ashiato wo ou, Josei to Keiken: 137-148.

Kawai Hayao 河合隼雄. 1983. Mukashibanashi to nihonjin no kokoro 昔話と日本人 の心. Tōkyō: Iwanami Shoten.

Kemenczky Judit (ford.). 1994. Nó-drámák (Középkori japán színjátékok). Budapest: Orpheus Kiadó.

Kobayashi Naoko 2017. „Sacred Mountains and Women in Japan: Fighting a Romanticized Image of Female Ascetic Practitioners." Japanese Journal of Religious Studies 44 (1) (Gendering Religious Practices in Japan): 103-122.

Komatsu Kazuhiko 小松和彦. 1991. Kamikakushi-ikai kara no izanai 神隠し, 異界から のいざない. Tōkyō: Kōbundō.

Konno Ensuke 今野圓輔. 2008. „Kamikakushi 神隠し.” In: Ōtsuka Minzokukai (eds.) Nihon minzoku jiten 日本民俗事典 Tōkyō: Kōbundō, 167.

Miyata Noboru 宮田登 1990. Yōkai no minzokugaku, nihon no mienai kūkan 妖怪の民 俗学, 日本の見えない空間. Tōkyō: Iwanami Shoten.

Mizoguchi Tsunetoshi 1989. „Slash-and-Burn Field Cultivation in Pre-Modern Japan: With Special Reference to Shirakawa-go."Geographical Review of Japan 62 (1): 14-34.

Németh Anita 2018. „Pokol és Paradicsom kapuja: az Osorezan.” In: Doma Petra, Takó Ferenc (szerk.) „,Közel, s Távol" VI. Az Eötvös Collegium Orientalisztika Mühely éves konferenciájának elöadásaiból, 2016. Budapest: Eötvös Collegium,83-106.

Ōshima Akio et al 大島暁雄 (ed.) 1990. Minzoku tanbō jiten 民俗探訪事典. Tōkyō: Yamakawa Shuppansha

Ōshima Tatehiko 大島建彦 2008. „Yōkai 妖怪.” In: Inada Kōji et al (eds.) Nihon mukashibanashi jiten 日本昔話事典. Tōkyō: Kōbundō, 994-995.

Papp Melinda 2018. „Tisztaság és tisztátalanság képzetei a japán népi kultúrában. A gyermekszületéshez kapcsolódó rítusok és tilalmak.” In: Déri Balázs - Kósa Gábor Vér Ádám (szerk.) Purum et immundum. Vallási elképzelések a tisztaságról és tisztátalanságról. Az Eötvös Loránd Tudományegyetem Bölcsészettudományi Karán 2016. október 14-15-én tartott vallástudományi konferencia elöadásai. (AГION könyvek 4) Budapest: Eötvös Loránd Tudományegyetem, Bölcsészettudományi Kar. Vallástudományi Központ, 122-134.

Papp Melinda - Zentai Judit 2019. „Gyógyítók és gyógyítás a folklór és orvostörténet tükrében a Meiji előtti Japánban.” Távol-Keleti Tanulmányok 10 (1): 149-170.

Rumánek, Ivan R.V. 2010. Japonská dráma nó. Žáner vo vývoji. Bratislava: Veda, Slovenská akadémia vied.

Sakurai Tokutarō 桜井徳太郎 2008. „Fujo 巫女.” In Ōtsuka Minzokukai (eds.) Nihon minzoku jiten 日本民俗事典. Tōkyō: Kōbundō, 616-617.

Strausz Janka 2016. „Az idegenek szemlélete a japán közösségi érintkezések tükrében.” Távol-keleti Tanulmányok 8: 111-130. 
Takashima Yōko 高島葉子 2001. „Shuryōkami toshiteno yamauba no genkei. Kitagata shominzoku no ke no onna shujin no ruijisei wotegakari ni 狩猟神としての山姥の 原形一北方諸民族の獣の女主人の類似性を手がかりに.”Jinbun kenkyū: Ōsaka shiritsu daigaku daigakuin bungaku kenkyūka kiyō 53(7): 123-137.

Wakamori Tarō 和歌森太郎 1976. „Onna no isshō 女の一生.” In: Nihon no minzoku 日本 の民俗 vol.6. Tōkyō: Kawade Shobō.

Yanagida Kunio 柳田國男 1988. Tōno Monogatari 遠野物語. Tōkyō: Daiwa Shobō.

Yanagida Kunio 柳田國男 2013. Yōkai Dangi 妖怪談義. Tōkyō: Kadokawa Sofia Bunko.

Yoshida Atsuhiko 吉田敦彦 1992. Mukashibanashi no kōkōgaku - Yamauba to Jōmon no onnakami 昔話の考古学 - 山姥と縄文の女神. Tōkyō: Chūkōshinsho.

Zentai Judit Éva 2015. „A tradicionális kínai és az európai koncepciók egyidejű alkalmazása a japán orvostudományban és anatómiában." Kaleidoscope Müvelödéstudomány-és Orvostörténeti Folyóirat 11: 12-22. 